\title{
PENGARUH MINAT DAN KREATIVITAS BELAJAR MATEMATIKA TERHADAP HASIL BELAJAR SISWA KELAS X
}

\author{
Sadriwanti Arifin \\ Dosen STIE Mujahidin Tolitoli \\ E-mail: sadriwantiarifin@gmail.com
}

\begin{abstract}
ABSTRAK
Penelitian ini merupakan penelitian ex-post facto yang bersifat koresional.Masalah yang diselidiki dalam penelitian ini adalah keterkaitan variabel minat dan kreativitas terhadap hasil belajar matematika.Data dikumpulkan diolah dengan menggunakan analisis statistik "SPSS dan Minitab". Hasil analisis menunjukkan bahwa minat belajar matematika diperoleh skor rata-rata 73,14 dari skor ideal 125 dengan standar deviasi 13,613. Kreativitas belajar matematika dengan skor ratarata 63,35 dari skor ideal 100 dengan standar deviasi 7,183 dan hasil belajar matematika dengan skor rata-rata 15,73 dari skor ideal 25 dengan standar deviasi 2,933. Selanjutnya pengujian hipotesis dengan menggunakan analisis regresi linear ganda diperoleh kesimpulan bahwa (1) minat belajar matematika mempunyai pengaruh terhadap hasil belajar matematika siswa kelas X SMA (2) kreativitas belajar matematika tidak mempunyai pengaruh terhadap hasil belajar matematika siswa kelas X SMA (3) minat belajar dan kreativitas belajar matematika secara bersama-sama mempunyai pengaruh terhadap hasil belajar matematika siswa
\end{abstract}

Kata Kunci: Minat, Kretaivitas Siswa, Hasil Belajar

\section{PENDAHULUAN}

Dalam rangka mencerdaskan kehidupan bangsa, yang kian hari selalu penuh dengan tantangan, maka pendidikan sangatlah memegang peranan penting suatu bangsa akan berhasil apabila memiliki tingkat pendidikan yang sudah maju dalam menghadapi perkembangan zaman yang penuh dengan persaingan. Oleh sebab itu, salah satu kunci yang paling besar peranannya adalah peningkatan kualitas manusia dan untuk mendapatkan hal tersebut tidak terlepas dari peningkatan kualitas pendidikan karena apabila kualitas pendidikan sudah tercapai, maka sumber daya manusia dapat lebih meningkat.

\section{A. Pengertian Minat}

Minat merupakan salah satu aspek psikologis yang mempengaruhi kualitas pencapaian hasil belajar siswa.Minat merupakan sikap batin yang diekspresikan dan menunjukkan bahwa seseorang menyukai dan memberi perhatian besar terhadap suatu hal atau aktivitas. Selain itu timbul perasaan senang untuk mengenang beberapa hal atau aktivitas tersebut dan sekaligus terlibat sepenuhnya dengan kegiatan yang menyangkut hal atau aktivitas tersebut. 
Mengingat pentingnya minat tumbuh dalam diri seseorang, maka seseorang siswa pun sangat diharapkan memiliki minat terhadap berbagai hal atau aktivitasnya. Daya mengingat bahan pelajaran juga bertalian erat dengan konsentrasi terhadap pelajaran. Ingatan mungkin tercapai kalau siswa berminat terhadap pelajarannya. Dengan kata lain minat memilki peranan mempermudah dan memperkuat pelajarannya melekat dalam ingatan.

\section{B. Minat Belajar Matematika}

Keberadaan minat juga sangat diperlukan dalam kegiatan belajar matematika untuk mencapai hasil yang lebih baik perlu adanya minat yang tertanam dalam diri siswa mengenai hal atau aktivitas yang berkaitan dengan belajar matematika. Keberhasilan dalam belajar matematika tidak lepas dari minat yang dimiliki oleh seorang siswa, karena seorang yang mempunyai minat yang besar akan merasa senang dan penuh perhatian dalam belajar matematika, sehingga dapat mencapai hasil belajar yang baik.

Dari uraian di atas dapat disimpulkan bahwa minat belajar matematika adalah kecenderungan dan kegairahan yang tinggi untuk memberikan perhatian yang lebih besar sekaligus terlibat sepenuhnya dalam kegiatan belajar matematika.

\section{Minat Belajar Dan Hasil Belajar Matematika}

Berdasarkan teori reinsforment bahwa belajar adalah hasil penguatan yang dipengaruhi oleh faktor internal dan eksternal. Sudjana (2002:56) mengatakan bahwa faktor yang mempengaruhi belajar meliputi, faktor interen, yaitu faktor jasmani, faktor fsikologis antara lain minat, perhatian, intelegensia, bakat, motif, kematangan, kesiapan dan kelelahan. Faktor ekstern antara lain adalah faktor keluarga, sekolah dan masyarakat.

Keterlibatan sistem secara aktif dalam proses belajar mengajar siswa dapat tercapai apabila siswa memiliki minat terhadap matematika karena apabila siswa mempunyai minat terhadap matematika akan merasa senang dan penuh perhatian mengikuti pelajaran dan pada akhirnya akan mencapai hasil belajar yang baik. Hal ini mengandung arti bahwa seseorang siswa akan sukar mencapai hasil belajar yang baik dan benar tanpa adanya minat.

Dalam kehidupan masyarakat sering didengar orang yang mampu mengubah barang bekas atau sampah menjadi sesuatu yang bermanfaat, disebut orang yang kreatif atau mempunyai kreativitas, tetapi orang yang mampu mengangkat barbell seberat $22 \mathrm{~kg}$ tidak disebut kreatif melainkan disebut orang yang luar biasa. Dari kasus ini nampak bahwa untuk menjadi kreatif tidak sulit jika kita mempunyai keinginan untuk berbuat kepekaan terhadap permasalahan yang ada di sekitar kita. 
Dalam belajar matematika, suatu hal yang signifikan untuk diperhatikan adalah adanya peran aktif, keseriusan, ketekunan, dalam menghadapinya. Hal ini dimaksudkan agar potensi intelektual individu dapat tumbuh dan berkembang secara positif dan produktif. Pengalaman belajar sebelumnya sangat berpengaruh dalam membangun kesadaran dan afirmasi positif terhadap mata pelajaran yang diajarkan di lembagalembaga pendidikan formal, termasuk bidang studi matematika. Dengan demikian, belajar dengan konsteks matematika merupakan suatu proses aktif dan sengaja dikakukan untuk memperoleh pengetahuan baru.

Hal tersebut di atas menunjukkan bahwa belajar matematika merupakan kegiatan aktif dalam melihat, mengamati, memikirkan, dan memahami ide-ide atau simbol-simbol yang ada dalam struktur matematika. Sebagai suatu kegiatan yang aktif, maka dalam belajar matematika seorang siswa akan mengalami atau menghadapi berbagai permasalahan. Untuk mengatasi permasalahan tersebut, maka kreativitas seorang siswa sangat besar peranannya. Kreativitas di sini bukanlah merupakan suatu yang belum penah diketahui oleh orang sebelumnya melainkan bahwa produk kreativitas ini merupakan suatu yang baru bagi dirinya dan tidak harus baru bagi orang lain atau dunia pada umumnya. Kreativitas dalam hal ini merupakan proses berpikir dimana siswa berusaha unuk menemukan hubungan-hubungan baru, mendapat jawaban, metode, atau cara dalam memecahkan masalah.

\section{Kreativitas Dan Hasil Belajar Matematika}

Materi matematika tersusun secara hirarkis, sehingga untuk mempelajarinya diperlukan proses berpikir secara kontinu, dengan demikian proses belajar matematika akan berjalan lancar jika matematika sebelumnya dapat diterapkan.

Hal di atas menunjukkan bahwa kreativitas atau cara berfikir kreatif besar peranannya dalam proses belajar matematika, karena proses berfikir semua kegiatan mental yang menyelesaikan persoalan baru atau mengajukan baru atau pandangan baru terhadap suatu persoalan lama. Dan orang yang kreatif yang lebih banyak bekerja dalam otaknya serta dapat menggunakan gagasan lama yang telah dipelajarinya.

Senada dengan ini, perlu dikemukakan bahwa proses kreativitas ada dua cara berfikir yang terlibat yaitu berfikir konvergen dan berfikir divergen. Berfikir konvergen apabila individu diminta untuk memuaskan semua yang telah diketahui berasal dari pengalaman- pengalaman yang lampau guna memperoleh suatu jawaban yang benar atau mendekati kebenaran. Sedangkan berfikir divergen apabila dengan informasi yang 
diberikan individu dapat dibayangkan elemen-elemen atau rencana. Rencana yang baru atau memberikan beberapa kemungkinan jawaban.

Hasil belajar matematika seseorang dapat dilihat dari kemampuannya menyelesaikan soal-soal matematika dan materi-materi yang sudah dipelajarinya, ini berarti cara berfikir konvergen dan divergen besar peranannya dalam menentukan hasil belajar matematika.

Berdasarkan beberapa pengertian belajar yang telah dikemukakan di atas dapat ditarik suatu kesimpulan bahwa pada umumnya para ahli dalam memberikan batasan atau pengertian tentang belajar lebih menekankan pada perubahan tingkah laku pada individu yang belajar. Perubahan tersebut tidak hanya berkaitan dengan ilmu pengetahuan, tetapi juga berbentuk kecakapan, keterampilan, sikap, minat, watak, penyesuaian diri dan lainlain.

\section{E. Hasil Belajar Matematika}

Dalam kamus umum bahasa indonesia prestasi diartikan sebagai hasil yang telah dicapai (dilakukan, dikerjakan) Poerwardaminto (1984:768). Jika dikaitkan dengan belajar matematika, maka hasil belajar matematika adalah suatu hasil yang dicapai atau diperoleh siswa dalam menekuni dan mempelajari matematika atau dikaitkan secara sadar sebagai hasil belajar dari interaksi. Hasil belajar matematika dikatakan berhasil jika pemahaman konsep yang dicapai sudah mampu diaplikasikan dalam proses belajar untuk menyelesaikan soal pada mata pelajaran matematika.

Dari pendapat di atas diperoleh gambaran bahwa hasil belajar adalah kemampuan yang diperoleh siswa setelah melalui kegiatan belajar. Belajar itu sendiri merupakan proses dari seseorang yang berusaha untuk memperoleh perubahan prilaku yang relatif menetap. Dikaitkan dengan matematika, maka hasil belajar matematika merupakan hasil belajar yang dicapai siswa setelah mengikuti proses belajar matematika dalam selang waktu tertentu. Berdasarkan uraian yang telah dikemukan di atas maka masalah yang akan diselidiki dalam penelitian ini dirumuskan sebagai berikut:

1. Apakah minat belajar matematika mempunyai pengaruh positif terhadap hasil belajar matematika siswa Kelas X SMA?

2. Apakah kreativitas belajar matematika mempunyai pengaruh positif terhadap hasil belajar matematika siswa?

3. Apakah minat dan kreativitas belajar matematika secara bersama-sama mempunyai pengaruh terhadap hasil belajar matematika siswa? 


\section{METODE PENELITIAN}

Jenis penelitian ini adalah penelitian tindakan kelas yang pelaksanaannya meliputi perencanaan, tindakan, observasi/evaluasi, dan refleksi yang selanjutnya tahapan- tahapan tersebut dirangkai dalam suatu siklus kegiatan.Untuk memperoleh data yang diperlukan dalam penelitian, dilakukan dengan memberikan angket dan tes. Angket yang diberikan adalah skala minat dan angket kreativitas, sedangkan tes yang diberikan adalah tes hasil belajar matematika.

Untuk mengukur skor setiap variabel penelitian digunakan instrumen sebagai berikut:

\section{A. Skala Minat}

Skala minat belajar yang diberikan kepada responden adalah angket yang dibuat oleh peneliti. Angket disusun dalam bentuk skala Likert. Setiap pertanyaan dalam angket disertai dengan lima alternatif jawaban dengan cara pemberian skor dengan mengikuti prosedur penelian skala Likert sebagai berikut:

Tabel 1. Tabel Skor Skala Likert Minat

\begin{tabular}{llll}
\hline \multicolumn{1}{c}{ Untuk pertanyaan positif } & \multicolumn{2}{c}{ Untuk pertanyaan negatif } \\
\hline Selalu (SL) & 5 & Selalu (SL) & 1 \\
Sering (SR) & 4 & Sering (SR) & 2 \\
Kadang-Kadang (KK) & 3 & Kadang-Kadang (KK) & 3 \\
Jarang (JR) & 2 & Jarang (JR) & 4 \\
Tidak Pernah (TP) & 1 & Tidak Pernah (TP) & 5
\end{tabular}

Sumber : Sudjana, Tahun: 2002

\section{B. Angket Kreativitas}

Angket kreativitas yang diberikan kepada responden adalah angket yang dibuat oleh peneliti. Angket ini berisi penilain aspek kepribadian, cara berfikir, dan kebiasaan belajar. Adapun indikator kreativitas sebagai berikut :

1. Cara berfikir meliputi : Berpikir konvergen dan divergen dalam proses belajar matematika, cepat mengemukakan pendapat dan panjang akal dalam belajar matematika.

2. Kepribadian meliputi : Mandiri dalam belajar matematika, percaya diri secara intelektual, berkemauan keras untuk menyelesaikan soal-soal matematika menanggapi pertanyaan-pertanyaan.

3. Kebiasaan meliputi : Bergairah, aktif dan bersemangat dalam menyelesaikan jawaban. Senang mencari metode praktis, agresif bertanya dan mencari penyelesaian. 
Untuk angket kreativitas juga disusun dalam bentuk skala Likert. Setiap pertanyaan dalam angket disertai dengan lima alternatif jawaban dengan cara pemberian skor dengan mengikuti prosedur penilaian skala Likert sebagai berikut:

Tabel 2. Tabel Skor Skala Likert Kreativitas

\begin{tabular}{llll}
\hline \multicolumn{1}{c}{ Untuk pertanyaan positif } & \multicolumn{2}{c}{ Untuk pertanyaan negatif } \\
\hline Sangat Setuju (SS) & 5 & Sangat Setuju (SS) & 1 \\
Setuju (S) & 4 & Setuju (S) & 2 \\
Netral (R) & 3 & Netral (R) & 3 \\
Tidak setuju (TS) & 2 & Tidak setuju (TS) & 4 \\
Sangat tidak setuju (STS) & 1 & Sangat tidak setuju (STS) & 5 \\
\hline
\end{tabular}

Sumber : Sudjana, Tahun: 2002

\section{Tes Hasil Belajar}

Tes hasil belajar adalah tes yang dikembangkan sendiri oleh penulis dengan bentuk pilihan ganda dengan empat alternatif jawaban berdasarkan kurikulum yang berlaku dan materi yang diajarkan oleh gurunya . Skor untuk tes hasil belajar matematika adalah jumlah skor dari jawaban siswa yang benar. Jika siswa menjawab benar diberi skor 1, sedangkan jika siswa menjawab salah diberi skor 0 .

\section{HASIL PENELITIAN DAN PEMBAHASAN}

\section{A. Hasil Belajar Matematika}

Hasil analisis statistik deskriptif yang berkaitan dengan skor variabel hasil belajar disajikan pada tabel 3

Tabel 3. Statistik Deskripstif Hasil Belajar Matematika

\begin{tabular}{lc}
\hline \multicolumn{1}{c}{ Statistik } & Nilai statistik \\
\hline Ukuran sampel & 51 \\
Skor Ideal & 25 \\
Skor maksimum & 22 \\
Skor minimum & 9 \\
Skor rata-rata & 15,73 \\
Variansi & 8,603 \\
Standar deviasi & 2,933 \\
\hline
\end{tabular}

Sumber : Data Primer, Tahun: 2017

Pada tabel 3 tersebut diperoleh informasi bahwa skor rata-rata hasil belajar matematika adalah 15,73 dari skor ideal 25 yang mungkin dicapai untuk keperluan pengkategorian skor responden. Pengkategorian dikelompokkan ke dalam lima kategori, maka diperoleh distribusi skor tersebut seperti yang tertera pada tabel 4 berikut : 
Tabel 4. Distribusi Frekuensi Dan Persentase Skor Hasil Belajar Matematika

\begin{tabular}{ccccc}
\hline Interval & Skor & Kategori & Frekuensi & Persentase \\
\hline $0 \%-34 \%$ & $0-8,5$ & Sangat rendah & 0 & $0 \%$ \\
$35 \%-54 \%$ & $8,6-13,5$ & Rendah & 10 & $19,61 \%$ \\
$55 \%-64 \%$ & $13,6-16$ & Sedang & 21 & $41,18 \%$ \\
$65 \%-84 \%$ & $16,1-21$ & Tinggi & 19 & $37,25 \%$ \\
$85 \%-100 \%$ & $21,1-25$ & Sangat tinggi & 1 & $1,96 \%$ \\
\hline & Jumlah & & 51 & 100 \\
\hline
\end{tabular}

Sumber : Data Primer, Tahun: 2017

Tabel 4. menunjukkan bahwa banyak siswa dalam kategori rendah, sedang, dan tinggi, sedangkan pada tabel 3 menunjukkan bahwa skor rata-rata adalah 15,73 dengan kategori sedang. Jadi dapat disimpulkan bahwa hasil belajar matematika siswa

\section{B. Minat Belajar Matematika}

Hasil analisis statistik deskriptif yang berkaitan dengan skor interval minat belajar disajikan pada tabel 5

Tabel 5. Statistik Deskriptif Skor Minat Belajar Matematika

\begin{tabular}{cc}
\hline Statistik & Nilai statistik \\
\hline Ukuran sampel & 51 \\
Skor ideal & 125 \\
Skor maksimum & 99 \\
Skor minimum & 50 \\
Skor rata-rata & 73,14 \\
Variansi & 185,321 \\
Standar deviasi & 13,613
\end{tabular}

Sumber : Data Primer, Tahun: 2017

Pada tabel 5. tersebut diperoleh informasi bahwa skor rata-rata minat belajar matematika adalah 73,14 dari skor ideal 125 yang mungkin dicapai. Jika skor variabel ini dikelompokkan kedalam lima kategori, maka diperoleh distribusi skor tersebut seperti pada tabel. 6 berikut: 
Tabel 6. Distribusi Frekuensi Dan Persentase Skor Minat Belajar Matematika

\begin{tabular}{|c|c|c|c|}
\hline Skor & Kategori & Frekuensi & Persentase \\
\hline $25-37,5$ & Sangat rendah & 0 & $0 \%$ \\
\hline $37,6-62,5$ & Rendah & 14 & $27,45 \%$ \\
\hline $62,6-87,5$ & Sedang & 30 & $58,82 \%$ \\
\hline $87,6-112,5$ & Tinggi & 7 & $13,73 \%$ \\
\hline $112,6-125$ & Sangat tinggi & 0 & $0 \%$ \\
\hline \multicolumn{2}{|c|}{ Jumlah } & 51 & 100 \\
\hline
\end{tabular}

Sumber : Data Primer, Tahun: 2017

Tabel. 6 menunjukkan bahwa 58,82\% siswa memiliki minat belajar matematika dalam kategori sedang. Pada tabel 5 menunjukkan bahwa skor rata-rata adalah 73,14 dan termasuk dalam kategori sedang. Jadi dapat disimpulkan bahwa minat belajar matematika siswa

\section{Kreativitas Belajar Matematika}

Hasil analisis statistik deskriptif yang berkaitan dengan variabel kreativitas belajar disajikan pada tabel 7

Tabel 7. Statistik Deskriptif Skor Kreativitas Belajar Matematika

\begin{tabular}{cc}
\hline Statistik & Nilai statistik \\
\hline Ukuran Sampel & 51 \\
Skor ideal & 100 \\
Skor maksimum & 80 \\
Skor minimum & 50 \\
Skor rata - rata & 63,35 \\
Variansi & 51,593 \\
Standar deviasi & 7,183 \\
\hline
\end{tabular}

Sumber : Data Primer, Tahun: 2017

Tabel.7 menunjukkan bahwa 84,31\% siswa memiliki kreativitas belajar matematika dalam kategori sedang. Pada tabel 7 menunjukkan bahwa skor rata-rata adalah 63,35 dan termasuk dalam kategori sedang. Jadi dapat disimpulkan bahwa kreativitas belajar matematika siswa

\section{Hasil Analisis Statistik Inferensial}

a. Pengujian persyaratan analisis

Sebelum teknik analisis regresi digunakan, maka terlebih dahulu diadakan uji persyaratan analisis. Persyaratan yang dimaksud adalah uji normalitas dan uji linieritas. Uji pernyataan ini dilakukan melalui program komputer.

1) Uji Normalitas 
Pengujian kenormalan dilakukan dengan komputer program pengolahan data "SPSS" dengan metode uji normalitas Kolmogorov-Smirnov. Pengujian kenormalan disajikan dalam bentuk diagram probabilitas normal dengan mempergunakan taraf signifikan $\alpha=0,05$

Jika $\mathrm{H}_{0}=$ data berasal dari populasi berdistribusi normal

$\mathrm{H}_{1}=$ data tidak berasal dari populasi

Dengan kriteria yang digunakan yaitu terima $\mathrm{H}_{0}$ apabila nilai Sig. lebih dari tingkatan $\alpha$ yang ditentukan. Nilai Sig. Hasil belajar matematika sebesar 0,039, minat sebesar 0,018 dan kreativitas sebesar 0,049 lebih dari tingkatan $\alpha$ yang ditentukan maka $\mathrm{H}_{0}$ diterima dan $\mathrm{H}_{1}$ ditolak. Hal ini menunjukkan bahwa data minat, kreativitas dan hasil belajar matematika berasal dari populasi berdistribusi normal.

2) Uji kecocokan model ( linieritas )

Pengujian kecocokan model (linieritas) dilakukan dengan komputer program pengolahan data "Minitab" dengan metode uji F. Dari uji F, diperoleh F = 55,09 dengan P $=0,000$ dan $\alpha=0,05$ maka dapat disimpulkan bahwa secara linear model sudah dapat digunakan untuk memprediksi hasil belajar matematika.

Karena pengujian analisis terpenuhi maka dilanjutkan dengan uji hipotesis dengan menggunakan regresi linear ganda matematika, dengan kata lain minat belajar matematika $\left(\mathrm{X}_{1}\right)$ dan kreativitas belajar matematika $\left(\mathrm{X}_{2}\right)$ dapat digunakan sebagai prediksi hasil belajar matematika siswa (Y).

\section{b. Pengujian hipotesis}

Untuk keperluan pengujian hipotesis digunakan analisis regresi linier ganda dengan taraf signifikan $\alpha=0,05$ dengan model regresi yang digunakan adalah :

$$
\hat{\mathrm{Y}}=\mathrm{b}_{0}+\mathrm{b}_{1} \mathrm{X}_{1}+\mathrm{b}_{2} \mathrm{X}_{2}
$$

Hasil analisis regresi dengan menggunakan program komputer. Rangkuman analisis tersebut dapat dilihat pada tabel 8 dan tabel 9 dibawah ini :

Tabel 8. Hasil Anova dari Regresi Linier Ganda diantara $Y, X_{1}$ dan $X_{2}$

\begin{tabular}{cccccc}
\hline Model & DF & SS & MS & F & P \\
\hline Regresi & 2 & 299,62 & 149,81 & 55,09 & 0,000 \\
Kesalahan & 48 & 130,54 & 2,72 & & \\
\hline
\end{tabular}

Sumber : Data Primer, Tahun: 2017 
Tabel 9. Nilai $t$ dan $\mathrm{P}$ untuk estimator $\beta \mathrm{i}$

\begin{tabular}{ccccc}
\hline Varians & COEF & SE COEF & T & $\boldsymbol{p}$ \\
\hline Konstanta & 1,352 & 2,099 & 0,64 & 0,522 \\
$\mathrm{X}_{1}$ & 0,17268 & 0,01929 & 8,95 & 0,000 \\
$\mathrm{X}_{2}$ & 0,02752 & 0,3656 & 0,75 & 0,455
\end{tabular}

Sumber : Data Primer, Tahun: 2017

1) Uji hipotesis pertama $(Y)$

Dari program analisis data "Mini Tab" diperoleh persamaan regresi linier ganda antara hasil belajar matematika dengan minat dan kreativitas belajar matematika sebagai berikut :

$$
\mathrm{Y}=1,35+0,173 \mathrm{X}_{1}+0,0275 \mathrm{X}_{2}
$$

Hasil perhitungan pada diperoleh nilai $\mathrm{p}=0,0000$ yang lebih kecil dari taraf signfikan $\alpha=0,05$. Hal ini menunjukkan Ho ditolak. Jadi dapat disimpulkan bahwa minat dan kreativitas belajar matematika secara bersama-sama berpengaruh terhadap hasil belajar siswa

Konstribusi minat belajar dan kretaivitas belajar matematika mempunyai pengaruh secara bersama-sama terhadap hasil belajar matematika siswa sebesar $68,4 \%$ diperoleh dari nilai koefisien determinasi sebesar 69,7\%.

2). Uji hipotesis kedua $\left(\mathrm{X}_{1}\right)$

Untuk menguji hipotesis kedua digunakan nilai $\mathrm{P}$ dengan variabel bebas minat belajar matematika. Kriteria penolakan $\mathrm{H}_{0}$ yaitu $\mathrm{P} \geq \alpha$ maka $\mathrm{H}_{0}$ ditolak dan $\mathrm{H}_{1}$ diterima. Hasil perhitungan menunjukkan nilai $\mathrm{P}=0,000$ yang lebih kecil dari pada taraf signifikan $\alpha=0,05$, ini berarti bahwa $\mathrm{H}_{0}$ ditolak. Karena $\mathrm{H}_{\mathrm{o}}$ ditolak maka implikasinya minat belajar matematika mempunyai pengaruh positif terhadap hasil belajar matematika siswa dengan memperhitungkan variabel kreativitas pada taraf signifikan $\alpha=0,005$.

3). Uji hipotesis ketiga $\left(X_{2}\right)$

Untuk menguji hipotesis ketiga digunakan nilai $\mathrm{P}$ dengan variabel bebas kreativitas belajar matematika. Kriteria penolakan $\mathrm{H}_{0}$ yaitu $\mathrm{P} \leq \alpha$ maka $\mathrm{H}_{0}$ ditolak dan $\mathrm{H}_{1}$ diterima. Hasil perhitungan diperoleh nilai $\mathrm{P}=0,455$ yang lebih besar dari pada tarapf signifikan $\alpha=0,05$. Ini berarti bahwa $\mathrm{H}_{0}$ diterima atau implikasinya kreativitas belajar 
matematika tidak berpengaruh terhadap terhadap hasil belajar matematika siswa dengan memperhitungkan vaiabel minat.

\section{KESIMPULAN DAN SARAN}

\section{A. Kesimpulan}

Berdasarkan hasil analisis statistik deskriptif dan statistik inferensial, maka dapat disimpulkan sebagai berikut:

1. Hasil belajar matematika siswa tergolong sedang dengan skor rata-rata 15,73 dari skor ideal 25 dengan standar deviasi 2,933.

2. Minat belajar matematika siswa tergolong sedang dengan skor rata-rata 73,14 dari skor ideal 125 dari standar deviasi 13,613.

3. Kreativitas belajar matematika tergolong sedang dengan skor rata-rata 63,35 dari skor ideal 100 dengan standar deviasi 7,183.

4. Minat belajar berpengaruh positif terhadap hasil belajar matematika siswa dengan memperhatikan kreativitas belajar matematika.

5. Kreativitas belajar matematika tidak berpengaruh terhadap hasil belajar matematika

6. Minat belajar dan kreativitas belajar matematika bersama-sama berpengaruh terhadap hasil belajar matematika.

\section{B. Saran}

Berdasarkan kesimpulan diatas, maka dikemukakan saran-saran sebagai berikut :

1. Disarankan kepada guru matematika agar dalam usaha meningkatkan hasil belajar matematika

2. Minat belajar matematika dalam upaya meningkatkan hasil belajar siswa dengan banyak memberikan soal-soal latihan yang lebih banyak memiliki muatan-muatan berhitung.

3. Kepada peneliti di bidang pendidikan agar dapat mengadakan penelitian lebih lanjut, guna keperluan hasil penelitian ini, misalnya variabel penelitian diteliti pada populasi yang lain atau variabel bebas, penelititan ini diselisiki pengaruhnya terhadap hal-hal lain maupun bidang studi lain. 


\section{DAFTAR PUSTAKA}

Adinawan, Cholik. 2006. Matematika SMP Jilid 1A kelas VIII. Jakarta: Erlangga.

Hudoyo, Herman, 1990. Strategi Mengajar Belajar Matematika. Malang: IKIP Malang.

Hartono, 2006. Peningkatan Hasil Belajar Matematika Melalui Pendekatan Pembelajaran Aktif, Kreatif, Efektif dan Menyenangkan Pada Siswa Kelas VIII SMP Negeri 26 Makassar. Skripsi Universitas Muhammadiyah Makassar, Makassar.

Poerwardaminto, W. J. S.1984. Kamus Umum Bahasa Indonesia. PN. Balai Pustaka.

Rosmiati. 2007. Pengaruh Kemampuan Awal dan Cara Belajar Terhadap Prestasi Belajar Matematika siswa kelas VII SMP Negeri MangaraBombang Kabupaten Takalar. Skripsi Universitas Muhammadiyah Makassar, Makassar.

Sudjana. 2002. Metode Statistik. Bandung: Tarsito. 